\title{
SIINDROME DE RUBÉOLA CONGÉNITA: PRIMER CASO CLÍNICO EN CHILE POST PROGRAMA DE REVACUNACIÓN
}

\author{
Enrique Valdés R. ${ }^{1}$, Paula Candia P. ${ }^{2}$, Hernán Muñoz S. ${ }^{1}$ \\ 1 Unidad de Medicina Materno Fetal, Hospital Clínico Universidad de Chile. ${ }^{2}$ Unidad de Medicina Materno Fetal, \\ Hospital Barros Luco Trudeau.
}

\section{RESUMEN}

Se presenta el primer caso clínico de síndrome de rubéola congénita en Chile, posterior al programa de revacunación en 1999. Se describe el caso índice y se realiza una breve revisión actualizada del tema.

PALABRAS CLAVE: Síndrome de rubéola congénita, vacuna antirubéola, complejo TORCH

\section{SUMMARY}

We present the first clinical case of congenital rubella syndrome (CRS) in Chile after the preconceptional vaccination campaign in 1999. This report describes the case and we present a brief review of CRS.

\section{KEY WORDS: Congenital rubella syndrome, rubella vaccine, TORCH complex}

\section{INTRODUCCIÓN}

El virus de la rubéola fue el primer virus en demostrar teratogénesis en la especie humana, causando el Síndrome de Rubéola Congénita (SRC) caracterizado por graves secuelas tempranas, persistentes y tardías. Gracias a las campañas de prevención en los países que presentan un programa de vacunación, sobre todo preconcepcional, el SRC es raro. Si bien esta enfermedad afecta tradicionalmente a los niños, en los brotes de 1997 y 1998 se observó que más del $70 \%$ de los casos se produjo en personas entre los 10 y 29 años (74\% en 1997 y $78 \%$ en 1998) afectando en la mitad de los casos a la población femenina. Hecho este diagnóstico y con el objetivo de evitar el SRC, en 1999 se efectuó una campaña de vacunación dirigida a mujeres entre 10 y 29 años, alcanzando una cobertura del $95 \%$ de la población.
El objetivo de este reporte es dar a conocer el primer caso de SRC en Chile post programa de revacunación, sospechado antenatalmente.

\section{Caso Clínico}

Primigesta de 16 años, sin antecedentes mórbidos de importancia, quien acude a la Unidad de Medicina Fetal del Hospital Clínico de la Universidad de Chile por ultrasonografía de rutina a las 22 semanas de gestación, donde se diagnostica hidrocefalia fetal moderada $(15 \mathrm{~mm})$ y foco hiperecogénico en ventrículo derecho. Se solicita evaluación con ultrasonido en 3D corroborando la hidrocefalia. Debido a los hallazgos se solicita estudio serológico materno de síndrome de TORCH. Estudio que confirma infección antigua para Citomegalovirus, negatividad para Parvovirus B19 y Toxoplasmosis, y positividad para IgM e IgG para virus Rubéola. 
Por lo anterior se solicita nueva serología materna a los 15 días para evaluar evolución de los títulos, que muestran un alza de los niveles de ambas inmunoglobulinas (Tabla I).

\section{Tabla I \\ SEROLOGÍA DE RUBÉOLA MATERNO - NEONATAL. CASO ÍNDICE}

\begin{tabular}{lcc}
\hline Edad gestacional & $\lg M$ & $\lg G$ \\
\hline 23 semanas & 0,25 & 12,4 \\
25 semanas & 0,90 & 34,6 \\
Sangre de cordón umbilical & 0,32 & - \\
\hline
\end{tabular}

Debido a que en Chile no está disponible el estudio de avidez, se sugiere a la paciente estudio confirmatorio del ambiente intrauterino que es rechazado por la madre. La evolución del embarazo es fisiológico asistiéndose parto vaginal a las 38 semanas, de recién nacido femenino, adecuado para la edad gestacional, peso: $3.100 \mathrm{~g}$ y talla: $49 \mathrm{~cm}$, Apgar 9-10. Al momento del parto se toma muestra de sangre de cordón umbilical que se envía para estudio serológico, que confirma la presencia de IgM para rubéola. Estudio por imágenes del neonato (TAC y RNM) concluye hidrocefalia y quiste del plexo coroideo. Recién nacido se de alta en buenas condiciones generales junto a su madre al tercer día de vida.

\section{DISCUSIÓN}

La rubéola es una enfermedad exantemática, de curso benigno, de distribución mundial, no evidenciándose la existencia de reservorio en animales ni de insectos, y que ocurre predominantemente en la infancia, pero con efectos potencialmente devastadores para el feto (1).

El agente responsable es un virus RNA de la familia Togaviridae estrechamente relacionado al grupo Arbovirus A. Fue el primer virus aislado en cultivo de tejidos en 1962 y responsable de teratogénesis. El poder de contagio de la infección se considera moderado, ocurre principalmente en el invierno, adquiriéndose por contacto con las secreciones nasofaríngeas de la persona infectada. El período de incubación es de 16 a 18 días en promedio, con un rango de 14 a 23 días; mientras que el período de transmisibilidad es de aproximadamente una semana antes, y por lo menos cuatro días después de comenzar la erupción, que dura aproximadamente tres días. Se pesquisa viremia materna después de 7 días del contagio y durante esta etapa es probable la infección transplacentaria por vía hematógena.

La sintomatología en las embarazadas, presente en el $50-70 \%$ de los casos, se caracteriza por la presencia de artralgias (75\%) sumada al exantema típico, linfaadenopatías y sintomatología respiratoria moderada. El curso frecuentemente es benigno y autolimitado, describiéndose en casos excepcionales encefalitis $(1 / 6000)$ con una alta mortalidad $(50 \%)$, manifestaciones hemorragíparas secundaria a trombocitopenia (1/3000), neuritis y conjuntivitis.

En Chile en 1998, la incidencia de rubéola en mujeres en edad fértil fue de 35/100.000 habitantes, estimándose que la seropositividad en este grupo poblacional alcanza al 95\%. Cabe destacar que durante los brotes y epidemias entre el 10 al $15 \%$ de las gestantes susceptibles contraen la infección $(2,3)$.

Greeg, en 1941, fue el primero que describió la tríada característica del SRC: cardiopatía congénita, cataratas y sordera. Posteriormente estudios en animales corroboraron los mismos hallazgos encontrados en los fetos humanos; defectos cardiacos, oculares, esqueléticos, SNC (caso índice) restricción del crecimiento fetal y óbito, siendo mayor el riesgo de teratogénesis cuando la infección ocurre en el periodo de la organogénesis (Tabla II) Por otra parte, entre el 50 y $70 \%$ de los fetos infectados nacen aparentemente normales presentando posteriormente alguna anomalía (4).

Cabe destacar que la sospecha diagnóstica en el estudio ultrasonográfico prenatal de SRC comparte hallazgos imagenológicos con el síndrome de TORCH, siendo los signos de mayor importancia las cardiopatías congénitas, calcificaciones intracerebrales, restricción del crecimiento intrauterino, microcefalia e hidrocefalia (caso índice) (5).

Tabla II

RIESGO DE SÍNDROME RUBÉOLA CONGÉNITA (SRC) DURANTE EL EMBARAZO

\begin{tabular}{cc}
\hline $\begin{array}{c}\text { Edad gestacional } \\
\text { (semanas) }\end{array}$ & $\begin{array}{c}\text { Riesgo de transmisión } \\
\text { vertical (\%) }\end{array}$ \\
\hline $6-8$ & 100 \\
$8-12$ & 80 \\
$13-16$ & $45-50$ \\
$17-20$ & 6 \\
21 & 0 \\
\hline
\end{tabular}

Fuente: Ghidini A, Linch I. Prenatal diagnosis and significance of fetal infection. West J Med. 1993;159:366-73. 
El diagnóstico se basa en métodos de laboratorio directos e indirectos, los primeros tendientes a aislar al agente o partículas virales por medio del aislamiento a través de cultivo o por amplificación de su material genómico (PCR) y los indirectos basados en el estudio serológico materno y/o fetal. En la serología materna el examen se basa en la detección y cuantificación de las concentraciones de $\lg \mathrm{M}$ e $\lg \mathrm{G}$ en sangre y el comportamiento de estos títulos en suero agudo y convaleciente (ELISA, IFA HI) (6-8).

El estudio invasivo se puede realizar a través de la muestra de vellosidad corial, amniocentesis y cordocentesis por medio del aislamiento viral directo, estudio del genoma viral (hibridación y PCR) y/o IgM ó IgA en sangre de cordón, este último a realizarse en embarazos mayores de 22 semanas $(7,8)$.

Hasta el año 1998, la rubéola había permanecido como una enfermedad endémica en muchos países Latinoamericanos y del Caribe, estimándose que hasta esa fecha anualmente existían 20.000 nuevos casos de SRC, no escapándose Chile de esta realidad (3). Por lo anterior el Ministerio de Salud en el año 1999 lanzó la "Campaña Nacional de Vacunación contra la Rubéola en mujeres de 10 a 29 años". Esta campaña de vacunación se insertó dentro de una estrategia global de prevención del Síndrome de Rubéola Congénita, que pretende eliminar este problema de nuestro país. Los objetivos de esta estrategia eran: 1) disminuir la población en edad fértil susceptible a la enfermedad, a través de la campaña de inmunización masiva en mujeres entre 10 y 29 años; 2) ampliar la capacidad de laboratorio para el diagnóstico de certeza frente a la sospecha de casos; 3) evaluar el impacto de las medidas de control implementadas, a través de un sistema nacional de vigilancia de la rubéola congénita y 4) mantener y mejorar la vacunación programática en niños de ambos sexos. Para los fines de seguimiento de esta estrategia de salud, se clasificaron los casos índices en tres categorías:

1.Caso de infección: es el que tiene evidencia de laboratorio pero sin síntomas o signos clínicos; para el sistema de vigilancia que se propone este caso puede darse entre los hijos de madres con antecedente de rubéola durante el embarazo.

2.Caso sospechoso: tiene algún hallazgo clínico compatible con SRC, sin evidencia de laboratorio.

3.Caso confirmado: caso sospechoso con confirmación de laboratorio, a través de identificación de IgM en muestras de sangre del niño. Estos son los que se clasificarán como niños con síndrome de rubéola congénita para este sistema.

A nivel internacional se utilizan además otras categorías como son el caso probable (que tenga al menos dos anomalías asociadas a SRC) y caso consistente (que sea clínicamente compatible pero que por alguna razón no se pudo obtener confirmación por laboratorio) (2).

A pesar de esta campaña de revacunación, a partir de marzo de 2007 apareció un brote epidémico de rubéola en Chile que se extendió desde las I y IX regiones. Las nuevas infecciones ocurrieron principalmente en hombres $(97 \%)$, las mujeres afectadas correspondieron a personas que por diversas razones no fueron vacunadas, no existiendo a la fecha de la redacción de este artículo otra notificación de SRC (9). La genotipología del virus que afecta a nuestro país es el $2 \mathrm{~B}$, el mismo que esta presente en Brasil desde el año 2006 y que circula actualmente en Europa, lo que hace pensar una introducción del virus a partir de este continente.

Pese a las estrategias de prevención de la SRC utilizadas en países desarrollados, se han reportado casos aislados de transmisión vertical lo que refleja la dificultad de erradicar esta patología debido a la incompleta cobertura de las campañas de revacunación preconcepcional, a la parcial inmunización que otorga la vacuna en el tiempo (10 años) y a que en Chile esta estrategia de salud excluyó a los hombres, hizo que la aparición de un brote en este grupo genérico fuera punto de partida de contagio a la población femenina en edad fértil (caso índice).

En resumen, se presenta el primer caso de infección congénita de rubéola confirmada en Chile, posterior a campaña de vacunación preconcepcional. Se sugiere a los especialistas sospechar este síndrome frente a la pesquisa de hallazgos fetales patológicos en el examen ultrasonográfico prenatal.

\section{BIBLIOGRAFÍA}

1. De Santis M,Cavalliere A, Straface G, Caruso A. Rubella infection in pregnancy. Reproductive Toxicology 2006;21:390-8.

2. Ministerio de Salud. RUBÉOLA. Boletín de vigilancia epidemiológica de Chile. El vigía 1999;2(7):1-23. Hallada en: http://epi.minsal.cl/epi/html/elvigia/VigiaExtra. pdf).

3. Hinman AR, Hersh BS, de Quadros CA. Rational use of rubella vaccine for prevention of congenital rubella syndrome in the Americas. Rev Panam Salud Publica 1998;4(3):156-60.

4. Gregg NM. Congenital cataract following German measles in the mother. Trans Ophthalmol Soc Aust. 1941;3:35-46

5. Degani S. Sonographic findings in fetal viral infections: A systematic review. Obstet Gynecol Survey 2006;61(5):329-36.

6. Gabutti G, Rota MC, Salmaso S, Bruzzone BM, Bella 
A, Crovari P. Serologycal Study Group. Epidemiology measles, mumps and rubella in Italy. Epidemiol Infect 2002;129;(3):543-50.

7. Daffos F, Forestier F, Grangeot-Keros L, Capella M, Lebon $\mathrm{P}$, ChartierM, et al. Prenatal diagnosis of congenital rubella. Lancet 1984;2(8393):1-3.
8. Ghidini A, Linch I. Prenatal diagnosis and significance of fetal infection. West J Med 1993;159:366-73.

9. Ministerio de Salud. RUBÉOLA. Boletín de vigilancia epidemiológica de Chile. El vigía 2007. Hallado en: http://epi.minsal.cl/epi/html/Actualidad/Nacional/BroteRubeola2007. Consultado el 22/12/2007. 